\title{
Değerli Konut Vergisinin Belediye Vergileri ile Karşılaştırmalı Olarak ve Özellik Arz Eden Durumları Çerçevesinde İncelenmesi
}

\author{
DOI: $10.26466 /$ opus. 933217
}

\footnotetext{
Şebnem Ekeryılmaz ${ }^{*}$ Semra Altıngöz Zarpl1 ${ }^{* *}$

* Dr. Öğr. Üyesi, Bilecik Şeyh Edebali Üniversitesi/İ̈BF, Bilecik/Türkiye

E-Posta: sebnem.ekeryilmaz@bilecik.edu.tr

ORCID: 0000-0001-6033-2574

** Dr. Öğr. Üyesi, Bilecik Şeyh Edebali Üniversitesi/İ̈BF, Bilecik/Türkiye

E- Posta: semra.altingoz@bilecik.edu.tr

ORCID: $\underline{0000-0003-4597-0193}$
} $\ddot{O} z$

Değerli konut vergisi, Emlak Vergisi Kanunun 42 ve 49. maddeleri arasında hüküm altına alınmıştır. Değerli konut vergisi, Emlak Vergisi Kanunu içerisinde hüküm altına alınmasına rağmen emlak vergisinden farklı yönleri bulunmaktadır. Değerli konut vergisi, emlak vergisinden farklı olarak vergi değeri belli bir tutarm üzerinde olan konutlar vergilendirmeyi amaçlamaktadır. Değerli Konut Vergisi kapsammnda olan mesken nitelikli taşınmazlardan, Emlak Vergisi Kanununa göre belirlenen bina vergi değeri 2021 yll itibariyle belirlenen tutar ile, 5.227.000 Türk Lirası'nın üzerinde olanların vergilendirilmesi amaçlanmaktadır. Değerli konut vergisi, artan oranl vergi tarifesine sahip olması gerekçesiyle de vergilemede adalet ve ödeme gücü ilkesini göz önünde bulunduran bir vergidir. Değerli konut vergisinin hüküm altına alındığı 7194 Sayılı Kanun 5.12.2019 tarihinde yürürlüğe girmesine rağmen Değerli Konut Vergisi 2021 yllndan itibaren uygulanmaya başlanmıştır. Değerli konut vergisine ilişkin literatürde çok az sayıda çalışmaya rastlanmış olup, yeni bir düzenleme olması ve uygulamasına yeni başlanmış olması gerekçesiyle, değerli konut vergisinin ayrmtılı olarak incelenerek özellik arz eden durumlarmm ortaya konulması ve belediye vergileri ile karşılaştırmalı olarak incelenerek mevzuattaki sorunlu hususlara yönelik çözüm önerileri getirilmesi çalışmamızın literatüre katkısını oluşturmaktadır.

Anahtar Kelimeler: Servet Vergileri, Değerli Konut Vergisi, Belediye Vergileri. 


\title{
An Examination of the Valuable House Tax by Comparing It with Municipal Taxes and Considering Its Special Status
}

\begin{abstract}
The Valuable house tax has come into force with the Real Estate Tax Law Articles between 42 to 49. Although the Valuable house tax is included in the Real Estate Tax Law, it has different aspects from the Real estate tax. The primary difference is that the Valuable house tax aims at putting a tax on houses with a taxation value exceeding a certain amount. With the Valuable House Tax, it is aimed to tax the buildings with a tax value of more than TRL 5.227.000 according to the Real Estate Tax Law, as of 2021. With its progressive tax tariff, the Valuable house tax considers the principles of fairness and solvency in taxation. The Valuable house tax entered into force on 5.12.2019 with Law No. 7194, but its implementation has been initiated since 2021. There are very few studies in the literature on valuable house tax. Since it is a new regulation and its practice has just begun, revealing its prominent features by examining in detail, comparing it with municipal taxes, and proposing solutions to the problematic issues in the legislation will be contributions of our study to the literature.
\end{abstract}

Key Words: Wealth Taxes, Valuable House Tax, Municipal Taxes. 


\section{Giriş}

Türk vergi sistemimiz içerisinde vergiler; gelir, harcamalar ve servet üzerinden alınan vergiler olmak üzere üç grupta toplanmaktadır. Devlet topluma sunacağı kamu hizmetlerini yerine getirebilmek için ihtiyaç duyduğu mali kaynaklar içerisinde kamu giderlerinin finansmanını sağlayan en geniş paya sahip olan unsur gelir, servet ve harcamalar üzerinden alınan vergilerdir (Öz, Kutbay ve Buzkıran, 2014, s.87). Servet üzerinden alınan vergiler kapsamına; motorlu taşıtlar vergisi, veraset ve intikal vergisi ve emlak vergisi girmektedir. Servetin, ödeme gücünün göstergelerinden birisi olması gerekçesiyle ülkemizde servetten ve servetin el değiştirmesinden dolayı vergilendirme yapılmaktadır (Gerçek ve Ömür, 2017, s.207).

7194 sayılı 7.12.2019 tarihli Dijital Hizmet Vergisi ile Bazı Kanunlarda ve 375 Sayılı Kanun Hükmünde Kararnamede Değişiklik Yapılması Hakkında Kanun ile vergi tabanını genişletmek üzere yeni vergiler yürürlüğe girmiştir (Özkan, 2020, s.122). Yürürlüğe giren vergilerden birisi de değerli konut vergisidir. Değerli konut vergisine ilişkin düzenlemeler her ne kadar Emlak Vergisi Kanunu içerisinde yer alsa da yeni bir servet vergisi niteliğindedir.

2021 yılından itibaren uygulanacak olan değerli konut vergisi, değeri yüksek olan konutlardan artan oranlı bir vergi alınmasını gerektirmektedir ve mükellefin mesken nitelikli tek konutu yani oturduğu ev değerli konut vergisinden muaf tutulmuştur (Çelikkaya, 2020, s.256).

Çalışmada incelediğimiz değerli konut vergisinin konusunu; Türkiye sınırları içerisinde bulunan ve bina vergi değeri 5.227.000 Türk Lirası üzerinde olan mesken nitelikli taşınmazlar oluşturmaktadır. Değerli konut vergisinin yeni bir düzenleme olması gerekçesiyle ayrıntılı olarak incelenmesi önem arz etmektedir.

Değerli konut vergisinin içerisinde düzenlendiği emlak vergisi ile bir takım benzer yönleri bulunmaktadır. Bunlar; mesken nitelikli taşınmazlar üzerinden vergilendirme yapılması, mükellefleri, matrahlarının advolerem olması ve mükellefiyetin bitmesi hususundadır.

Değerli konut vergisini emlak vergisinden ayıran farklı yönleri ise; kapsamı, muafiyet ve istisnaları, mükellefiyetin başlaması, verginin tar- 
hı, tahakkuku ve tahsili, ödeme zamanı, oranı, tarifesi ve pişmanlık ve ıslah müessesesinin uygulanmamasıdır.

Çalışmanın giriş bölümünden sonra ikinci bölümünde değerli konut vergisi ayrıntılarıyla incelenmiş, üçüncü bölümünde emlak vergisi incelenmiş, dördüncü bölümünde değerli konut vergisi ve emlak vergisinin benzer ve farklı yönleri karşılaştırmalı olarak incelenmiş, beşinci bölümde değerli konut vergisinin ayrıntılı olarak incelenmesi neticesinde özellik arz eden durumlar ortaya konmuş, altıncı bölümde İngiltere' de belediye vergisi uygulaması ülkemizdeki düzenleme ile karşılaştırmalı olarak incelenmiş ve yedinci bölüm olan sonuç ve öneriler kısmında ise mevzuatta düzenlenen fakat uygulamada sorun oluşturabilecek hususlara değinilerek çözüm önerileri getirilmiştir.

\section{Değerli Konut Vergisinin İncelenmesi}

Değerli konut vergisinin üzerinden alındığı husus Türkiye sınırları içinde olan mesken nitelikli taşınmazlardır. Fakat mesken nitelikli taşınmazların değerli konut vergisinin kapsamına girebilmesi için, vergi değerinin 29.12.2020 tarihinde yayımlanan Emlak Vergisi Kanunu Genel Tebliği ile 1.1.2021 yılından itibaren uygulanmak üzere güncellenen tutar ile 5.227.000 TL'yi aşması gerekmektedir.

Mesken nitelikli taşınmaz kavramı; mesken niteliğini taşıyan binalar ile birden fazla bağımsız bölümden oluşan binalarda her bir bağımsız bölümü ifade etmektedir. Gelir İdaresi Başkanlığının yayımladığı Değerli Konut Vergisi Uygulama Genel Tebliğinde her bir bağımsız bölümün vergilendirme açısından ayrı ayrı değerlendirileceği belirtilmiştir.

Değerli konut vergisi adından da anlaşılacağı üzere yalnızca konutları vergi kapsamına almaktadır. Konut dışında kullanılan örneğin işyeri şeklinde olan taşınmazlar değerli konut vergisinin kapsamına girmemektedir. Kapsamın bu şekilde dar tutulması değeri 5.227.000 TL ve üzerinde olan taşınmazların mesken olarak değerlendirilme sorunu ile karşı karşıya bırakacaktır.

Tebliğe göre taşınmazın mesken niteliğini taşıyıp taşımadığının anlaşılması için taşınmazın kayıtlardaki niteliğinin yanında fiilen kullanım durumunun da dikkate alınacağ ken niteliği taşıyıp taşımadığının tespiti de ancak yoklama ve vergi ince- 
lemesi gibi yollarla yani vergi denetiminin yapılması ile ortaya çıkacaktır. İlgili uygulama hükmü mükelleflerin değerli konut vergisini ödememelerinin önüne geçmek için öngörülmüştür. Mükellefler değerli konut vergisinden kaçınmak için kanunda yazılı tutarın üzerindeki binalarını mesken olarak tapuda tescil ettirmemesine rağmen fiilen mesken olarak kullanabilirler. Bu ihtimal çerçevesinde mükelleflerin, değerli konut vergisini ödememelerini önlemek için tebliğde böyle bir düzenlemeye yer verilmiştir.

Bina vergi değeri Emlak Vergisi Kanunun 29. maddesine göre hesaplanmaktadır. Değerli konuta ilişkin vergi değeri taşınmazın bulunduğu yerdeki belediyelerden temin edilecektir.

Değerli konut vergisinin mükellefi Emlak Vergisi Kanunun 45. maddesine göre; taşınmazların maliki, varsa intifa hakkı sahibi her ikisi de yoksa mesken nitelikli taşınmazı malik gibi tasarruf edenlerdir.

Malik kavramı Medeni Kanunun 683. maddesinde; hukuk düzeninin sınırları içerisinde, malik olunan şey üzerinde dilediği gibi kullanma, yararlanma ve tasarrufta bulunma yetkisine sahip olma hakkı olarak tanımlanmıştır.

Değerli konut vergisini, Emlak Vergisi Kanunun 45. maddesi gereğince, taşınmazın maliki öder. Mesken nitelikli taşınmazın üzerinde intifa hakkı varsa vergi bu hakka sahip olan kişi tarafından ödenir.

İntifa hakkı, mülkiyet hakkından sonra en fazla hak veren sınırlı olan ayni bir haktır. İntifa hakkı olan, kullanma ve ürünlerden yararlanma yetkisine sahiptir (Arpacı, 2014, s.983). İntifa hakkı Medeni Kanunun 795. maddesine göre, taşınmazlarda tapu kütüğüne tescil ile kurulmaktadır. Dolayısıyla değerli konutlarda da intifa hakkı tapu kütüğüne tescil ile doğar ve bu hak sahibi değerli konut vergisini ödemekle yükümlü hale gelir.

Değerli konutun, maliki veya intifa hakkı sahibi bulunmaması durumunda değerli konut vergisini malik gibi tasarruf eden kişiler öder. Ancak malik veya intifa hakkı sahibinin bulunmaması durumu, değeri yüksek ve dolayısıyla değerli konut vergisine tabi olan taşınmazlarda görülme olasılığı düşük bir ihtimaldir.

Değerli konut vergisine ilişkin mükellefiyetin başlamasının üç şekilde olacağ1 Emlak Vergisi Kanunun 45. maddesinde düzenlenmiştir. Bu durumlar aşağıdaki şekildedir. 
- Mesken nitelikli taşınmazın bina vergi değerinin 5.227.000 TL'nin üzerinde olmasıdır.

- Emlak Vergisi Kanunun 33. maddesinde hüküm altına alınan vergi değerini değiştiren durumların meydana gelmesidir. İlgili durumlar; yeni bina inşa edilmesi ${ }^{1}$, binanın yanması, yıkılması veya diğer sebeplerle tamamen veya kısmen harap duruma gelmesi, binada mevcut asansör veya kalorifer tesislerinin kısmen veya tamamen kaldırılması, binanın kullanış tarzının değiştirilmesi, binanın mükellefinin değişmesidir.

- Kanunda hüküm altına alınmış olan muafiyetin herhangi bir sebeple bitmesidir.

Yukarıda yazılı olan durumlar meydana geldiğinde değerli konut vergisine ilişkin mükellefiyet takip eden yıldan itibaren başlar. Bina vergi değerinin ilgili yılda kanunda belirtilen tutarı aşması halinde, bu durumun gerçekleştiği tarihi takip eden yılın başından itibaren değerli konut vergisi mükellefiyeti başlayacaktır.

Yanma, yıkılma ve tamamen kullanılmaz hale gelme gerekçesiyle veya vergiye tabi iken muaflık şartlarını elde eden mesken nitelikli taşınmazların mükellefiyeti ise bu olayların meydana geldiği tarihi takip eden taksitten itibaren sona erecektir.

Değerli Konut Vergisi Uygulama Genel Tebliğine göre; değerli konut vergisine tabi olan mesken nitelikli taşınmazların daha sonraki yıllarda bina vergi değerinin, beyannamenin verileceği yılda geçerli olan kanunda belirtilen tutarın altında kalması halinde, bu durumun mükellef tarafından belgeler ile kanıtlanarak vergi dairesini bildirilmesi halinde ilgili yıla ilişkin beyanname verilmesine gerek kalmayacaktır.

Değerli konut vergisine tabi olan mükellefler, 2020 yılında bina vergi değeri kanunda yer alan tutarı aşan mesken nitelikli taşınmazlarına ilişkin 2021 yılının Şubat ayının 20. günü sonuna kadar beyannamelerini verecekler ve Şubat ve Ağustos olmak üzere iki eşit taksitte ödeyeceklerdir (Duran, 2019, s.673). Mükellefler beyannamelerini elektronik ortamda da verebileceklerdir. Değerli Konut Vergisi Uygulama Genel Tebliğinde yer aldığı üzere mükelleflerin, mesken nitelikli taşınmazın bulunduğu

\footnotetext{
${ }^{1}$ Emlak Vergisi Kanunun 33. maddesine göre, mevcut binalara ilaveler yapılması veya asansör veya kalorifer tesisleri konulması da yeni inşaat hükmündedir.
} 
yer belediyesinden alınan beyanname verilen yıl ve bir önceki yıla ilişkin bina vergi değerini gösteren belgeyi de beyannamelerine ekleyerek taşınmazların bulunduğu yer yetkili vergi dairelerine beyannamelerini vermeleri gerekmektedir. Kanunda düzenlemese de uygulama genel tebliğinde her yıl için verilen beyannameye, beyannamenin verildiği yıl ve bir önceki yıla ilişkin bina vergi değerini gösteren belgenin eklenmesi zorunlu tutulmuştur. Bunun yanında, gelir veya kurumlar vergisi yönünden mükellefiyeti bulunan mükellefler ise değerli konut vergisi beyannamelerini bağlı bulundukları vergi dairelerine verecektir.

Değerli Konut Vergisi Uygulama Genel Tebliğinde, yıl içerisinde değerli konut vergisine tabi olan mükelleflerden beyannamesini verip ilk taksitini ödeyip ikinci taksiti gelmeden yani Ağustos ayından önce taşınmazını satanlar açısından da vergi mükellefiyetinin devam edeceği belirtilmiştir. Mükellefler mesken nitelikli taşınmazlarını satsalar bile yıl içerisindeki değerli konut vergisine ilişkin taksitleri ödeme yükümlülükleri devam etmektedir. Mükellefiyetin başladığı 1 Ocak ile 20 Şubat arasında taşınmazını satması durumunda da beyannamesine bu taşınmazını dahil edecek ve vergisinin tamamını ödemekle yükümlü olacaktır. Mükellefin taşınmazı satmasına rağmen mükellefiyetinin ilgili yıl içerisinde devam etmesi vergi ödenmemesinin önüne geçmek için bir güvence tedbiri olarak tebliğde öngörülmüştür. Mesken nitelikli taşınmazı satın alan kişinin mükellefiyeti ise takip eden yılda da kanunda belirtilen tutarı aşması halinde takip eden yıldan itibaren başlayacaktır.

Bu hususa Değerli Konut Vergisi Uygulama Genel Tebliğinde yer verilmiş olup, Emlak Vergisi Kanununda açıkça bu duruma ilişkin bir düzenleme getirilmemiştir. Mükelleflerin ilgili hususta tereddüt etmemeleri ve vergilerini geç ödememeleri açısından bu duruma kanunda da açıklık getirilmesi hukuki güvenlik ve belirlilik ilkeleri açısından da yerinde olacaktır.

Değerli konut vergisine ilişkin muaflıklar Emlak Vergisi Kanunun 46. maddesinde hüküm altına alınmıştır. İlgili muafiyetler aşağıdaki gibidir.

- Genel ve özel bütçeli idarelerin, belediyelerin, üniversitelerin ve Toplu Konut İdaresi Başkanlığının sahibi olduğu mesken nitelikli taşınmazlar değerli konut vergisinden muaf tutulmuştur. İlgili kurumların intifa hakkına sahip oldukları mesken nitelikli taşın- 
mazlar da değerli konut vergisinden muaf tutularak taşınmazların mülkiyet sahipleri de değerli konut vergisini ödemeyecektir.

- Türkiye sinırları içerinde mesken nitelikli tek taşınmazı olanlar değerli konut vergisinden muaf tutulmuştur.

- Birden fazla mesken nitelikli taşınmazı olan mükellefler ise değerli konut vergisinin konusuna giren en düşük değerli mesken nitelikli tek taşınmazı değerli konut vergisinden muaf tutulmuştur.

- Karşılıklı olmak şartıyla yabancı devletlere ait olup elçilik ve konsolosluk olarak kullanılan mesken nitelikli taşınmazlar değerli konut vergisinden muaf tutulmuştur.

- Esas faaliyet konusu bina inşası olan kişilerin işletmelerine kayıtlı bulunan henüz ilk satışa, devir ve temlike konu edilmemiş yeni inşa edilen mesken nitelikli taşınmazlar vergiden muaf tutulmuştur.

Birden fazla mesken nitelikli taşınmazı bulunan mükellefler, değerli konut vergisinin konusuna giren en düşük değerli mesken nitelikli tek taşınmazı vergiden muaf tutulsa bile buna ilişkin beyanname verme süresi içerisinde vergi dairesine bildirim formu verilmesi gerektiği Değerli Konut Vergisi Uygulama Genel Tebliğinde yer almaktadır.

Değerli konut vergisinin matrahı Emlak Vergisi Kanununun 44. maddesinde bina vergi değerinin 5.227.000 TL'yi aşan kısmı olarak belirlenmiştir. 2021 yılından itibaren değerli konut vergisine tabi mesken nitelikli taşınmazlardan değeri 5.227.000 TL ile 7.841.000 TL arasında olanlar için 5.227.000 TL'yi aşan kısmı için binde 3 oranında vergiye tabi tutulacaktır. 10.455.000 TL'ye kadar olanlar 7.841.000 TL'si için 7.842 TL fazlasi için binde 6 oranında vergiye tabi tutulacaktır. 10.455.000 TL'den fazla olanlar bu tutar için 23.526 TL fazlası için binde 10 oranında vergiye tabi tutulacaktır.

Vergi değeri kanunda belirtilen tutarın üzerinde birkaç konutu olan ve bunlar içerisinde değerli konut vergisinden muaf olmayan vergi değeri 12.000.000 TL olan konuta ilişkin mükellefin ödeyeceği değerli konut vergisi tutarı yukarıda yer alan 2021 yılı tarifesine göre hesaplandığında 38.976 TL'dir.

Değerli konut vergisi artan oranlı vergi tarifesine sahiptir ve binde üç, binde altı ve binde on olmak üzere üç tane dilimi bulunmaktadır. Değerli 
konut vergisine ilişkin hesaplama yapılırken dikkat edilmesi gereken husus, ilk dilimde 5.227.000'yi aşan kısmın vergiye tabi tutulacağıdır. Burada verginin matrahını, bina vergi değerinin tamamı değil bina vergi değerinin kanunda yazılı tutarı aşan kısmı oluşturmaktadır.

Değerli konut vergisinin tahsiline ilişkin hüküm Emlak Vergisi Kanunun 48. maddesinde, emlak vergisinden farklı olarak hasılatının genel bütçeye kaydedileceği şeklinde hüküm altına alınmıştır.

\section{Emlak Vergisinin İncelenmesi}

Emlak, bina, arsa ve arazi şeklindeki gayrimenkullerden meydana gelen serveti ifade etmek üzere kullanılan bir kavramdır (Şenyüz, Yüce ve Gerçek, 2015: 375). Emlak vergisi ise, yerel toplumsal yaşamın ihtiyaçlarını karşılamak için belediyeler tarafından sunulması gereken kamu hizmetlerinin finansmanın sağlanması hususunda önemli gelir kaynaklarının başında gelmektedir (Anayasa Mahkemesinin 1.11.2017 tarihli 2016-43 Esas Sayılı 2017-146 Sayılı Kararı). Emlak vergisi, sabit varlıklar üzerinden alınan, objektif, yerel, gayri safi ve mülkilik ilkesine bağlı olan bir vergidir (Organ ve Çiftçi, 2015: 129).

1319 Sayılı Emlak Vergisi Kanunun birinci kısmında bina vergisi, ikinci kısmında ise arazi vergisi hüküm altına alınmıştır. Türkiye'nin coğrafi sınırları içerisinde bulunan taşınmazlar emlak vergisine tabi olmaktadırlar (Karagöz ve Arslan, 2019: 844). Emlak vergisi bina, arazi ve arsalardan alınan bir servet vergisidir (Pehlivan, 2020: 332).

Bina vergisinin matrahın, binanın kanun hükümlerine göre belirlenen vergi değeri oluşturmaktadır. Verginin oranı meskenlerde binde bir diğer binalarda binde iki olduğu, büyükşehir belediye sınırları ve mücavir alanlar içinde ise meskenlerde binde iki diğer binalarda binde dört olarak uygulanacağ 1 Emlak Vergisi Kanununda hüküm altına alınmıştır.

Emlak Vergisi Kanunun 8. maddesinde belirlenen şartlarını taşıyanlar için ise vergi oranlarını sıfıra kadar indirmeye Cumhurbaşkanı yetkili kılınmıştır. İlgili şartlar aşağıdaki gibidir.

- Hiçbir geliri olmadığını belgeleyenler,

- Gelirleri yalnızca kanunla kurulan sosyal güvenlik kurumlarından aldıkları aylıklardan ibaret olanlar, 
- Gaziler, engelliler, şehitlerin dul ve yetimlerin Türkiye sınırları içinde brüt $200 \mathrm{~m}^{2 \prime}$ yi geçmeyen tek meskenin maliki veya intifa hakkına sahip olmalarıdır.

Ancak yukarıdaki şartlardan birini taşısalar bile kendisine bakmakla mükellef kimsesi olup on sekiz yaşını doldurmamış olanlar kanun hükmünün dışında bırakılmışlardır.

Emlak Vergisi Kanunun ikinci kısmında düzenlenen arazi vergisinin matrahını da vergi değeri oluşturmaktadır. Arazi vergisinin oranı binde bir, arsalarda ise binde üçtür. Büyükşehir belediye sınırları ve mücavir alanlar içinde ise arazi vergisinin oranı binde iki, arsaların ise binde altıdir.

Emlak vergisine tabi olan mükelleflerin 2002 yılına kadar beyan esasına tabi olmalarına rağmen, 2002 yılında yürürlüğe giren 4751 sayılı kanunla, emlak vergisinde beyan yerine bildirim yükümlülüğ̈̈ getirilmiştir (Küpeli ve Saygın, 2019, s.2375).

Emlak vergisi, 1972 yılına kadar il özel idarelerince tahsil edilmiş ve \%25'i belediyelere verilmiştir. 1981 ve 1986 yılları arasında emlak vergisi tamamen merkezi yönetim geliri haline gelmiştir ve 2005 yılından itibaren tekrar emlak vergisi gelirinin tamamı belediyeler tarafından tahsil edilmiş ve belediyelerin geliri haline gelmiştir (Töremen, 2020, s.22).

\section{Değerli Konut Vergisi Ve Emlak Vergisinin Karşılaştırmalı Olarak İncelenmesi}

Değerli konut vergisi, emlak vergisi ile karşılaştırıldığında iki vergi arasındaki benzer yönlerinin, farklı yönlerden az olduğu görülmektedir.

Benzer yönlerinden biri, her iki vergide de mesken nitelikli taşınmaz üzerinden vergilendirme yapılmaktadır. Fakat değerli konut vergisinde sadece konutlar vergilendirilirken, emlak vergisinde konut niteliğindeki binalar yanında işyeri şeklinde olanlar ile arsa ve araziler de vergilendirilmektedir. Dolayısıyla emlak vergisinin kapsamı daha geniştir.

İkinci benzer yönü ise mükellefleri hususundadır. Her iki verginin mükellefi taşınmazın maliki, intifa hakkı sahibi her ikisinin de bulunmaması halinde ise malik gibi tasarruf eden kimselerdir.

Üçüncü benzer yönü her iki verginin matrahlarının da advolerem olmasıdır. Her iki vergide de matrah parasal bir değer olarak belirlenmiş 
ve bunun üzerinden kanunda belirlenen oranlarda vergi alınmaktadır. Her iki verginin matrahı advolerem olsa da emlak vergisinin matrahı, binanın veya arazinin kanuna göre tespit olunan vergi değeriyken, değerli konut vergisinde verginin matrahını, bina vergi değerinin 2021 yılı için 5.227.000 TL'yi aşan kısmı oluşturmaktadır.

Dördüncü benzer yönleri mükellefiyetin bitmesi hususundadır. Her iki vergide de, yanan, yıkılan, tamamen kullanılmaz hale gelen veya muaflık şartlarını kazanan taşınmazlarda, bu olayların meydana geldiği tarihi takip eden taksitten itibaren mükellefiyet sona ermektedir.

Değerli konut vergisi ile emlak vergisinin farklı yönleri, benzer yönlerine göre daha fazladır. Bu farklılıklar, kapsamı, muaflık ve istisnalar, mükellefiyetin başlaması verginin tarhı ve tahakkuku, ödeme zamanları, oranları, tarifesi ve tahsili hususundadır.

Değerli konut vergisi ile emlak vergisinin kapsamı karşılaştırıldığında emlak vergisinin kapsamının daha geniş olduğu görülmektedir. Değerli konut vergisinin kapsamına yalnızca konutlar girerken, emlak vergisinin kapsamına konutlar yanında işyeri ve benzeri amaçlarla kullanılan binalar, arsalar ve araziler de girmektedir.

Değerli konut vergisi ve emlak vergisine ilişkin muafiyet ve istisnalar yönünden benzerlikler bulunsa da farklılıklar daha fazladır. Aşağıdaki tabloda karşılaştırmalı olarak emlak vergisi ve değerli konut vergisine ilişkin muafiyet ve istisnalar yer almaktadır.

\section{Tablo 1.Muafiyet ve İstisnaların Karşılaştırması}

\section{Değerli konut vergisine ilişkin muafiyet ve istisnalarEmlak vergisine ilişkin muafiyet ve istisnalar}

Genel ve özel bütçeli idarelerin, belediyelerin, üniver- Özel bütçeli idarelere, il özel idarelerine, belediyelere, sitelerin ve Toplu Konut İdaresi Başkanlığının maliki köy tüzel kişiliğine, kanunla kurulan üniversitelere ve veya intifa hakkına sahip olduğu mesken nitelikli taşınmazlar. Devlete ait binalar. Kurumlar vergisine tabi işletmelere ait olmamaları veya bunlara tahsis edilmemeleri şartıyla kamu menfaatlerine yararlı derneklere ait binalar.

Türkiye sınırları içinde mesken nitelikli tek taşınmazı Mesken olarak kullanılan bina veya apartman daireleolanlar ile birden fazla mesken nitelikli taşınmazı rinin, 2.500 TL'den az olmamak üzere vergi değerinin bulunanların, değerli konut vergisi konusuna giren en $1 / 4$ ü, inşalarının sona erdiği yılı takip eden bütçe düşük değerli mesken nitelikli tek taşınmazı (intifa yılından itibaren 5 yıl süre ile geçici muafiyetten hakkına sahip olunması hâli dâhil) (Bu hüküm, belirti- faydalandırılır. Mükelleflerin bir belediye ve bu len kişilerin tek meskene hisse ile sahip olmaları belediyenin mücavir alan sınırları içinde bulunan hâlinde hisselerine ait kısım hakkında da uygulanır.). arazisinin (arsalar hariç) toplam vergi değerinin 10.000 TL'si vergiden istisnadır.

Yabancı devletlere ait olup elçilik ve konsolosluk Yabancı devletlere ait olup elçilik ve konsolosluk olarak kullanılan mesken nitelikli taşınmazlar ile olarak kullanılan binalar ile elçilerin ikametine mahsus elçilerin ikametine mahsus mesken nitelikli taşınmaz- binalar ve bunların müştemilatı (Karşılıklı olmak 
lar ve bunların müştemilatı (karşılıklı olmak şartıyla) şartıyla) ve merkezi Türkiye'de bulunan milletlerarası ve merkezi Türkiye' de bulunan milletlerarası kuruluş- kuruluşlara, milletlerarası kuruluşların Türkiye'deki lara, milletlerarası kuruluşların Türkiye'deki temsilci- temsilciliklerine ait binalar.

liklerine ait mesken nitelikli taşınmazlar.

Esas faaliyet konusu bina inşası olanların işletmelerine Kazanç amacı olmamak şartıyla işletilen hastane, kayıtlı bulunan ve henüz ilk satışa, devir ve temlike dispanser, sağlık, rehabilitasyon, teşhis ve tedavi konu edilmemiş yeni inşa edilen mesken nitelikli taşınmazlar (arsa karşılığı inşaat işlerinde sözleşme gereği taahhüt işini üstlenen müteahhide kalan mesken nitelikli taşınmazlar dâhil) (bu taşınmazların merkezleri, sanatoryum, prevantoryum, öğrenci yurtları, düşkünler evi, yetimhaneler, revirler, kreşler, kütüphaneler ve korunmaya muhtaç çocukları koruma birliklerine ait yurtlar ve işyerleri ile benzerleri. Din kiraya verilmesi veya diğer surette kullanılması hâllerihizmetlerin yerine getirilmesine yönelik ve umuma hariç). açı olan ibadethaneler ve müştemilatları.

Doğal afetler sebebiyle binaları yanan, yıkılan veya kullanılmaz hale gelen veya afetlerle zarar görmesi muhtemel yerlerdeki binaların vergi mükellefleri tarafından afetin gerçekleştiği veya afete maruz bulunduğunun yetkili kuruluşça tebliği tarihinden itibaren en geç 5 yıl içinde afetin gerçekleştiği yerde veya kamu kuruluşlarınca gösterilen yerlerde inşa edilen binalar inşalarının sona erdiği yılı, kamu kuruluşlarınca ilgili kanunlarına göre inşa olunup hak sahiplerine teslim edilen binalar devredildikleri yılı takip eden bütçe yılından itibaren 10 yıl süre ile geçici muafiyetten faydalanir.

Özel kanunlarına göre Devlet ormanları dışında insan emeğiyle yeniden orman haline getirilmek üzere ağaçlandırılan arazi 50 yıl vergiden muaf tutulmuştur. Toprak ve topoğrafik özellikleri ve erozyon gibi sınırlayıcı faktörler sebebiyle kültür bitkilerinin yetişmelerini engelleyen araziden; bataklık, turbiyer, çorak, makilik, çalılık, taşlık ve diğer haller dolayısıyla üzerinde tarım yapılamayan sahaların, sslah tedbirleriyle yeniden tarıma elverişli hale getirilmesinde 10 yıl vergiden muaf tutulmuştur.

Emlak vergisine ilişkin, kazanç amacı olmayan hastaneler, öğrenci yurtları ve korunmaya muhtaç çocuklara ait yurtlar ve benzerleri istisna kapsamında sayılırken değerli konut vergisinde bu gibi kurumlara yönelik istisnalara yer verilmemiştir. Değerli konut vergisine ilişkinde kazanç amacı olmayan buna benzer kurumların istisna kapsamına alınması daha yerinde olacaktır.

Değerli konut vergisinde Türkiye içerisinde mesken nitelikli tek taşınmazı olanlar ve birden fazla konutu olanlardan değerli konut vergisinin konusuna giren en düşük değerli mesken nitelikli tek taşınmazları verginin kapsamı dışında bırakılmıştır. Emlak vergisinde de mesken olarak kullanılan dairelerin vergi değerinin dörtte biri, inşaatlarının sona 
erdiği yılı takip eden yıldan itibaren beş yıl süre ile vergiden geçici muaf tutulmuştur. Emlak vergisine ilişkin beş yıllık geçici muafiyet kanunda hüküm altına alınmışken, değerli konut vergisinde süre kısıtlaması olmaksızın bir muafiyet söz konusudur.

Emlak vergisinde doğal afet gerekçesiyle kullanılmaz hale gelen binalar geçici süreliğine verginin kapsamı dışında bırakılırken, değerli konut vergisinde doğal afetlere ilişkin bir muafiyet kanunda öngörülmemiştir. Değerli konut vergisinde de doğal afet nedeniyle kullanılmaz hale gelen binalara ilişkin geçici muafiyet uygulanmasının daha yerinde olacağ 1 görüşündeyiz.

Emlak vergisi ve değerli konut vergisinde bir diğer farklılık matrahları hususundadır. Değerli konut vergisi artan oranlı tarifeye sahip bir vergidir ve binde 3 , binde 6 ve binde 10 olmak üzere üç farklı dilimi bulunmaktadır. Emlak vergisinin oranları ise taşınmazın mesken, arazi ve büyükşehir sınırları içerisinde yer alıp almamasına göre farklılık göstermektedir. Aşağıdaki tabloda karşılaştırmalı olarak emlak vergisi ve değerli konut vergisinin oranları yer almaktadır.

Tablo 2. Değerli Konut Vergisine İlişkin Oranlar ile Emlak Vergisine İlişkin Oranlar

\begin{tabular}{lll}
\hline Değerli Konut Vergisine İlişkin & Oranlar & \multicolumn{2}{l}{ Emlak Vergisine İlişkin Oranlar } \\
\hline & $\begin{array}{l}\text { Büyükşehir belediye } \\
\text { sinırları ve mücavir alanlar sınırları ve mücavir alanlar } \\
\text { içinde }\end{array}$ & $\begin{array}{l}\text { Büyüsşıhir belediye } \\
\text { dışa }\end{array}$ \\
\hline $\begin{array}{l}\text { 5.227.000 TL ile 7.841.000 TL arasında olanlar için } \\
\text { 5.227.000 TL'yi aşan kısmı için binde 3 }\end{array}$ & $\begin{array}{l}\text { Meskenler ve arazi vergisi } \\
\text { binde 2 }\end{array}$ & $\begin{array}{l}\text { Meskenler ve arazi vergisi } \\
\text { binde 1 }\end{array}$ \\
\hline $\begin{array}{l}\text { 10.455.000 TL'ye kadar olanlar 7.841.000 TL'si için } \\
\text { 7.500 TL fazlası için binde 6 }\end{array}$ & Arsalar binde 6 & Arsalar binde 3 \\
\hline $\begin{array}{l}\text { 10.455.000 TL'den fazla olanlar bu tutar için 23.526 } \\
\text { TL fazlası için binde 10 }\end{array}$ & $\begin{array}{l}\text { Mesken dışındaki binalarda Mesken dışındaki binalarda } \\
\text { binde 4 }\end{array}$ & binde 2 \\
\hline
\end{tabular}

Değerli konut vergisi, emlak vergisi ile karşılaştırıldığında artan oran11 vergi tarifesine sahip olması gerekçesiyle vergilemede mali güç ve adalet ilkesini daha fazla dikkate almaktadır. Mali güç ve vergilemede adalet ilkesi Anayasamızın 73. maddesinin birinci ve ikinci fıkrasında hüküm altına alınmıştır.

Değerli konut vergisinde, belli bir tutarın üzerindeki konutların vergilendirmesiyle ve artan oranlı tarifeye sahip olması ile vergileme ilkelerinden mali güç ve adalet ilkelerini emlak vergisine kıyasen daha fazla göz önünde bulundurarak vergileme yapılmaktadır. 
Emlak vergisi ve değerli konut vergisine ilişkin farklılıklardan bir tanesi de mükellefiyetin başlaması hususundadır. Değerli konut vergisinde mükellefiyet, mesken nitelikli taşınmazın bina vergi değerinin kanunda belirtilen tutarı aştığı, vergi değerini değiştiren sebeplerin doğdu$\breve{g u}$ ve muafiyetin ortadan kalktığ tarihi takip eden yıldan itibaren başlamaktadır. Emlak vergisi beyan esası yerine bildirim esasına dayanması gerekçesiyle mükellefiyet, dört yılda bir yapılan takdir işleminin yapıldığı, vergi değerini değiştiren değişikliklerin meydana geldiği ve muafiyetin ortadan kalktığı tarihi takip eden yıldan itibaren başlamaktadır.

Değerli konut vergisi ve emlak vergisine ilişkin önemli bir farklılık da tarh usullerine ilişkindir. Değerli konut vergisinde beyana dayanan tarhiyat yapılırken, emlak vergisi bildirim esasına dayanmaktadır. Emlak vergisinde beyan esası, 3.4.2002 tarihinde kabul edilen 4751 sayılı kanun ile kaldırılmıştır.

Değerli konut vergisi ve emlak vergisi arasındaki bir diğer farklılık ödeme zamanlarına ilişkindir. Değerli konut vergisinde kanunun 47. maddesinde hüküm altına alındığı üzere, şubat ayının 20. günü sonuna kadar beyanname verilir ve ilgili yılın şubat ve ağustos aylarında iki eşit taksitte ödenir. Emlak vergisi ise kanunun 30. maddesinde hüküm altına alındığı üzere, birinci taksiti Mart, Nisan ve Mayıs aylarında ikinci taksiti ise Kasım ayı içinde olmak üzere iki eşit taksitte ödenir.

Hasılatın toplanması hususunda da emlak vergisi ve değerli konut vergisi arasında farklılık bulunmaktadır. Emlak Vergisi Kanunun 48. maddesine göre, tahsil edilen değerli konut vergisi genel bütçe geliri olarak kaydedilir. Emlak vergisi, değerli konut vergisi gibi genel bütçe geliri olarak kaydedilmeyip, belediyeler tarafından tahsil edilen bir vergidir.

\section{Değerli Konut Vergisine İlişkin Özellik Arz Eden Durumların İnce- lenmesi}

Çalışmada, değerli konut vergisinin ayrıntılı olarak ve emlak vergisi ile karşılaştırmalı olarak incelenmesi neticesinde bu bölümde değerli konut vergisine ilişkin özellik arz eden durumlar ortaya konulmuştur.

Değerli konut vergisine ilişkin özellik arz eden durumlardan birincisi rant vergisi olup olmadığı hususundadır. 
Rant kavramı Türk Dil Kurumu Sözlüklerinde, "getirim" olarak tanımlanmıştır. Bir diğer tanımda geniş anlamda rant kavramı, "gayrimenkullerin değerinde meydana gelen ve emeğe dayanmayan artışlar" şeklinde ortaya konulmuştur (Ökmen ve Yurtsever, 2010, s.59).

Rant vergisi, arsa ve arazi spekülasyonları, nüfus artışı, sanayileşme, merkeze yakınlık, yapısal dönüşümler ve kamu kesiminin yaptığı hizmetlerden meydana gelen rantın vergilendirilmesi amacını taşımaktadır. Rant, bir gider karşılığı olmayıp, beklenilmezlik ve hak edilmemişliği de yapısında barındırmaktadır (Saraçoğlu, Çakar ve Çakır, 2015, s.84).

Gayrimenkule ilişkin rantların vergilendirilmesi hususunda uygulanan yöntemlerden birisi, bayındırlık veya imar faaliyetleri gerekçesiyle gayrimenkullerin değerinde meydana gelen artışların vergilendirilmesidir (K1lıçaslan ve Yavan, 2017, s.51).

Değerli konut vergisinin emlak vergisinden farklı yönlerinin fazla olması gerekçesiyle ayrı bir servet vergisi olduğu açıktır. Fakat Emlak Vergisi Kanunu kapsamında olan binalar, değerli konut vergisine ilişkin kanunda belirlenmiş olan tutarın altında kalınca sadece emlak vergisi tahsil edilmekte, kanunda yazılı tutarın üzerinde kalınca hem emlak vergisi hem de değerli konut vergisine tabi olmaktadır. Bu durumda binanın değerinin belli bir tutarı aşınca daha fazla vergi alınması halinin söz konusu olması gerekçesiyle değerli konut vergisinin de bir tür rant vergisi olduğundan bahsetmek mümkündür. Değerli konut vergisi kapsamına yalnızca mesken nitelikli taşınmazlar girdiği için dar kapsamlı bir rant vergisidir.

Değerli konut vergisine ilişkin özellik arz eden ikinci durum zamanaşımının başlaması hususundadır.

Emlak Vergisi Kanunun 40. maddesinde bina ve arazilerine ilişkin zamanaşımının, bina ve arazilerin bildirim dışı bırakıldığının idare tarafından öğrenildiği tarihi takip eden yılın başından başlayacağı hüküm altına alınmıştır. Fakat değerli konut vergisine ilişkin kanunda ve uygulama genel tebliğinde bu hususa ilişkin bir düzenleme bulunmamaktadır. Zamanaşımını düzenleyen hükümde bina ve araziler açık olarak ifade edilmekle birlikte değerli konutlara ilişkin bir ibare kanun maddesinde yer almamaktadır. Düzenleme bulunmaması durumu da değerli konut vergisine ilişkin zamanaşımı açısından Vergi Usul Kanununda yer alan hükümlerin geçerli olacağı anlamına gelmektedir. Dolayısıyla de- 
ğerli konut vergisine ilişkin zamanaşımı, Vergi Usul Kanunun 114. maddesinde düzenlendiği üzere, vergi alacağının doğduğu takvim yılını takip eden beşinci yılın sonunda gerçekleşecektir. Değerli konut vergisine ilişkin de bu hususa açıklık getirilip zamanaşımının başlamasının idarenin öğrendiği tarihe bağlanması daha yerinde olacaktır.

Değerli konut vergisine ilişkin özellik arz eden üçüncü durum, VUK'nun 371. Maddesinde hüküm altına alınan pişmanlık ve ıslah müessesesinin uygulanmasına ilişkindir.

Pişmanlık ve ıslah müessesesinin uygulanmasının beyana dayanan vergilerde geçerli olacağına açıkça kanun hükmünde yer verilmiştir. Emlak vergisinde 3.4.2002 tarihli 4751 Sayılı Kanunla beyan esasından bildirim esasına geçilmesi gerekçesiyle pişmanlık ve ıslah müessesesi emlak vergisi için uygulanmamaktadır. Nitekim pişmanlık ve islah müessesesini düzenleyen kanun maddesinde de emlak vergisi için uygulanmayacağı açık bir biçimde ifade edilmiştir.

Fakat Emlak Vergisi Kanunu içerisinde düzenlenen değerli konut vergisinin beyan esasına dayandığ 1 Emlak Vergisi Kanunun 47. maddesinde açık olarak düzenlenmiştir. Değerli konut vergisinin beyan esasına dayanması gerekçesiyle, değerli konut vergisine tabi olan mükellefler, VUK'nun 371. Maddesinde yazılı olan şartları yerine getirmeleri halinde pişmanlık ve ıslah müessesesinden yararlanabilmeleri gerekmektedir.

Değerli konut vergisine ilişkin özellik arz eden dördüncü durum ise değerli konut vergisi ödenmesinin emlak vergisi ödenmesine engel olmadığı hususundadır.

Kanunda ve uygulama genel tebliğinde yer verilmeyen bir diğer husus da değerli konut vergisine tabi olan mükelleflerin emlak vergisine tabi olup olmayacağıdır. Yasal düzenlemelerde bu hususa değinilmemesi, değerli konut vergisi ödeyen mükelleflerin aynı zamanda emlak vergisine de tabi olacağı anlamına gelmektedir. Vergilemede hukuki güvenlik ilkesi ve mükelleflerin vergi ödeme noktasında tereddüt etmemeleri açısından bu duruma da kanunda açıklık getirilmesi yerinde olacaktır.

Bunun yanında, konut dişında işyeri niteliğinde taşınmaza sahip olan veya arsa ve araziye sahip olan ve taşınmazlarının vergi değeri kanunda yazılı tutarı aşan mükellefler yalnızca emlak vergisi öderken, konutu olanlar ve vergi değeri kanunda yazılı tutarı aşanlar hem emlak vergisi hem de değerli konut vergisine tabi olmaları hususu vergilemede 
adalet ilkesini zedelemektedir. Aynı vergi konusunun hem yerel yönetimler tarafından hem de merkezi idare tarafından vergiye tabi tutulması çifte vergilendirme sorunu ortaya çıkacak ve en önemlisi de vergilendirmede adalet ilkesinin ihlal edilmesine sebep olacaktır (İşler ve Tümer, 2020, s.275).

Ayrıca değerli konut vergisi, mükellef gruplarını değeri 5.227.000 TL'yi geçen yurtiçi konut sahipleri olarak belirlemiştir. Aynı durumu yurtdışında belirli bir bedeli geçen konuta sahip vatandaşlar için belirlenmemiştir.

Vergi sistemimiz içerisinde yeni uygulamaya konulan değerli konut vergisi mükelleflerin taşınmazlarının toplam değerleri üzerinden değil, değeri 5.227.000 TL'yi geçen konut sayısı üzerinden belirlenmektedir. Bu durumda mükelleflerin mali gücüne göre davranılmadığını ve eşitlik ilkesinin göz ardı edildiğini göstermektedir.

Yerel yönetimlerin sunmuş olduğu hizmetlerden taşınmaz sahiplerinin faydalanması nedeniyle, emlak vergileri fayda vergisi kategorisinde değerlendirilebilmektedir. Vergilemede fayda yaklaşımı teorisinde, belirli kamu hizmetlerinden yararlanacak olan vatandaşların yararlanma oranlarında vergilerini ödeyerek kamu hizmetlerinin finansmanına katılmaları beklenmektedir (Hines, 2000, s.483). Burada kamu hizmetini sunan yerel yönetimler bu hizmetlerinin karşıllğında emlak vergisini tahsis edebilmektedir. Ancak değerli konut vergisinde yerel yönetim birimlerinden hizmet alınmış olsa da fayda vergisinin muhatabı merkezi idare olmaktadır.

Mahalli idarelerin önemli gelir kaynakları arasında yer alan emlak vergisinin merkezi idare tarafından toplanmamasının iki sebebi bulunmaktadır. Bunlardan ilki, vergi konusunun mahalli idare sınırları içerisinde kalması, ikincisi de verginin konusu olan emlakın mahalli idarenin gerçekleştirdiği hizmetlere entegre olmasıdır (Çetinkaya, 2014, s.73). Günümüzde emlak vergisi her ne kadar mahalli idarelerin gelir kaynakları arasında yer alsa da başlangıç itibariyle merkezi yönetimin gelir kaynakları arasında yer almaktaydı. Emlak vergisinin yaşamış olduğu bu süreç değerli konut vergisi için de söz konusu olabilmelidir. Değerli konut vergisinin matrahı belediyeler tarafından bina vergi değerinin asgari düzeyde tutulmasıyla gerçekleştirilmektedir. Belediyelere yüklenmiş olan bu sorumluluk karşısında tahsili gerçekleştirilen değerli ko- 
nut vergisi genel bütçe gelirleri arasına dahil edilmektedir. Fakat "Genel Bütçe Vergi Gelirlerinden Pay Verilmesi Hakkında Kanunun" kapsamına dahil edilmemektedir. Bu da belediyelerin bina vergi değerinin belirlenmesinde verimli ve etkin bir yol izlenememesine sebep olabilecektir.

Yerel yönetimlerin değerli konut vergisini toplama yetkisi olmadığ1 gibi büyükşehir belediyelerinin de emlak vergisi toplama yetkisi bulunmamaktadır. Fakat büyükşehir belediyeleri ilçe belediyelerinin tahsil ettiği gelirlerinden pay alabilmektedir.

\section{İngiltere'de Belediye Vergisi Uygulaması}

İngiltere'de belediye vergisi, birçok yerel yönetim için yerel gelirlerin ana kaynağıdır. 1 Nisan 1993'te, yerel vergilendirmede aktif rol oynayan baş vergisi, mülke dayalı bir vergi olan belediye vergisiyle değiştirilmiştir. Bu vergi sisteminde yurtiçi konutlar, piyasa değerlerine göre bantlama sistemine uyarlanmıştır. Bantlama sistemi, taşınmazların değerini, daha önceden belirlenen değer bantlarından birisine dahil ederek vergiye tabi tutulmaktadır. Yerel makamlar daha sonra genel belediye vergisi düzeyini belirlemektedir. Farklı bantlar için oranlar merkezi hükümet tarafından belirlenmektedir. Bu durum belediye vergisi uygulamaya konulduğundan beri değişmemiştir (Adam ve Browne, 2006, s.21).

İngiltere'de belediye vergisi olarak uygulanan emlak vergisi, Türkiye'de olduğu gibi yerel yönetimlerin uygulama alanı içerisinde yer almaktadırlar. Fakat ticari taşınmazlar için uygulanan vergi oranı ulusal kapsamda tayin edilmektedir. Ticari taşınmazlar üzerinde oluşturduğu vergi yükü sebebiyle, yerel yönetimlerin gelir kaynakları arasında önemli bir yere sahiptir. Ticari taşınmazlar üzerinden toplanan vergi merkez tarafından tahsil edilmektedir. Daha sonra yerel yönetimlere merkezi idare tarafından pay edilmektedir. Türkiye'de uygulamaya konulan değerli konut vergisi de merkezi idare tarafından tahsil edilmekte fakat belediye vergilerinin aksine yerel yönetimlere pay verilmemektedir (Önder, 2018, s.205).

Belediye vergisinde muafiyetler ve indirimler de uygulanmaktadır. Yalnızca bir yetişkinin ikametgahı olan mülkler için \% 25 indirim uygulanmakta ve eğer mülk boşsa veya ikinci bir ev ise \% 50 indirim uygu- 
lanmaktadır. Muafiyet hakkına sahip olanlar, öğrenci yurtları ve silahlı kuvvetlerin kışlalarıdır.

Düşük gelire sahip olan aileler, belediye vergisi ödeneği talep ederek belediye vergi faturalarının düşürülmesini veya ortadan kaldırılmasını talep edebilirler (Adam ve Browne, 2006, s.22).

Tablo 3.Ücretli konut sayısı 2015-2019 (Bin)

\begin{tabular}{|c|c|c|c|c|c|}
\hline \multicolumn{6}{|c|}{ Ücretli konut sayısı 2015-2019 (Bin) } \\
\hline & 2015 & 2016 & 2017 & 2018 & 2019 \\
\hline $\begin{array}{l}\text { Değerleme listelerinde yer alan } \\
\text { toplam konut sayısı }\end{array}$ & 23,652 & 23,863 & 24,076 & 24,298 & 24,549 \\
\hline $\begin{array}{l}\text { Belediye vergisinden muaf olan } \\
\text { konut sayısı }\end{array}$ & n531 & 542 & 568 & 599 & 626 \\
\hline & 2 & 1 & 1 & 1 & 1 \\
\hline \multicolumn{6}{|l|}{ Yıkılan konut sayısı } \\
\hline $\begin{array}{l}\text { Değerleme listesindeki beledi- } \\
\text { ye vergisine tabi mesken sayısı }\end{array}$ & 23,120 & 23,320 & 23,506 & 23,698 & 23,922 \\
\hline $\begin{array}{l}\text { İndirime veya prime tabi olan } \\
\text { konut sayss }\end{array}$ & 8,085 & 8,075 & 8,090 & 8,154 & 8,255 \\
\hline -ikinci evler & 27 & 22 & 19 & 15 & 13 \\
\hline indirime tabi boş evler & 107 & 93 & 79 & 72 & 64 \\
\hline prime tabi boş evler & 59 & 59 & 61 & 62 & 63 \\
\hline tek kişi & 7,653 & 7,657 & 7,680 & 7,738 & 7,837 \\
\hline $\begin{array}{l}\text { tüm sakinler belediye vergisi } \\
\text { amaçları için göz ardı edildi }\end{array}$ & 34 & 34 & 34 & 35 & 36 \\
\hline $\begin{array}{l}\text { biri hariç tümü göz ardı edildi } \\
\text { belediye vergisi amaçları için }\end{array}$ & 205 & 209 & 217 & 232 & 242 \\
\hline $\begin{array}{l}\text { İndirime veya prime tabi } \\
\text { olmayan konut sayısı }\end{array}$ & 15,035 & 15,245 & 15,417 & 15,545 & 15,667 \\
\hline boş evler & 283 & 290 & 314 & 338 & 356 \\
\hline ikinci evler & 219 & 225 & 230 & 237 & 240 \\
\hline diğerleri & 14,533 & 14,730 & 14,873 & 14,970 & 15,071 \\
\hline
\end{tabular}

Kaynak: Local Government Financial Statistics, 2020, s.9

Tablo'da 2015'ten 2019 yıllarına kadar İngiltere'de bulunan toplam konut sayısı yer almaktadır. Konutlar içerisinde, belediye vergisinden sorumlu olanlar, belediye vergisinden muaf olanlar, indirim alanlar, vergi ödemesi gerekenler ayrı ayrı belirtilmiştir. Yıllar itibariyle belediye vergisinden muaf olan konut sayıları artış göstermiştir. Türkiye'de değerli konut vergisinde değeri 5.227.000 Türk Lirasının üzerinde tek konuta sahip olan mükellefler muafiyete sahipken, belediye vergilerinde ikinci eve \%50 indirim uygulanmaktadır. 


\section{Sonuç ve Öneriler}

Değerli konut vergisi emlak vergisinden farklı olarak vergi değeri belli bir tutarı aşan konutları vergilendirmeyi amaçlamaktadır. Değerli konut vergisinin incelenmesi neticesinde ortaya çıkan özellikleri aşağıdaki gibidir.

- Servet üzerinden alınan bir vergidir.

- Mahalli bir vergi değildir çünkü toplanan hasılat genel bütçe gelirlerine hasslat kaydedilir.

- Vergi kanunlarının uygulama alanının belirlenmesinde iki adet ilke yer almaktadır. Bunlar; kanunların mülkiliği bir diğer adıyla yerselliği ve kanunların şahsiliği bir diğer adıyla kişiselliğidir. Kanunların mülkiliği ilkesi gereğince, bir ülkenin kanunları o ülkenin sınırları içerisindeki yerli ya da yabancı bütün kişilere ve hukuksal ilişkilere uygulanır. Şahsilik ilkesi ise, bir ülkenin uyruğundaki kişinin nerede bulunduğuna bakılmaksızın ülkesinin kanunlarına göre vergilendirilmesini gerektirmektedir (Kizılot ve Taş, 2013, s.23). Değerli konut vergisinde vergilendirme yapılırken mülkilik ilkesi uygulanmaktadır.

- Ödeme gücü ve adalet ilkesini dikkate alan bir vergidir. Bunun gerekçesini artan oranlı bir tarifeye sahip olması ve kişilerin tek mesken nitelikli taşınmazının vergiden muaf olması oluşturmaktadir.

- Sübjektif ve artan oranlı bir vergidir. Bütün mükellefler aynı oranda değerli konut vergisi ödemezler. Değerli konut vergisine ilişkin tarifede farklılaştırılmış üç adet dilim bulunmaktadır.

- Vergi matrahının parasal değer olarak belirlenip bunun belli bir oranından vergi alınması halinde advolerem tarife, matrahın kilogram, motor silindir hacmi gibi spesifik değerlerden olması halinde ise spesifik tarifeden söz edilir (Pehlivan, 2014, s.107). Değerli konut vergisi, advolerem tarifeye sahiptir.

Vergi kanunlarında vergilerin konusuna, mükelleflerine, muafiyet ve istisnalarına, oranlarına, tarifelerine ilişkin genel bir çerçeve çizilmektedir. Vergilerin uygulanmasına ilişkin ayrıntılı bilgiler uygulama genel tebliğlerinde yer almaktadır. Değerli Konut Vergisinde de bu duruma örnek olacak şekilde değerli konut vergisine tabi olan ve taşınmazlarını 
yıl içinde satan mükelleflerin, mükellefiyetinin ve verginin taksitlerini yıl içerisinde ödemeye devam edeceğine ilişkin kanunda bir düzenleme bulunmamasına karşın Değerli Konut Vergisi Uygulama Genel Tebliğinde bu duruma yer verilmiştir. Kanunlara her şeyin yazılması ve ayrıntılı olarak düzenlenmesinin kanunları karmaşık ve uzun hale getireceği düşüncesiyle ayrıntılara genel tebliğler de yer verilse de en azından temel konulara ve mükellefleri vergilerini ödeme noktasında tereddüt ettirmeyecek hususlara kanunlarda da yer verilmelidir. Aksi halde bu durum mükelleflerin vergilerini hiç ödememelerine, eksik veya geç ödemelerine sebep olabilecektir. Böyle olması da hem vergilerin hazineye intikalini geciktirecek hem de mükelleflerin istemeden de olsa bir takım vergi cezalarıyla karşı karşıya gelmelerine sebep olacaktır. Bu gibi olumsuz durumların önlenmesi ve vergilemede belirlilik, hukuki güvenlik dolayısıyla Anayasamız içerisinde yer alan hukuk devleti ilkesinin de ihlal edilmemesi için kanunlarda da bu gibi temel hususlara yer verilmesi daha yerinde olacaktır.

Değerli konut vergisi belli bir tutarın üzerindeki konutları vergilendirmektedir. Fakat vergi değeri 5.227.000 TL'nin altında olsa bile toplamda 5.227.000 TL'yi geçen birçok konutu bulunan mükellefin vergilendirilmesine yönelik bir düzenleme bulunmamaktadır. Bu durum da vergilemede adalet ilkesini zedelemektedir. Bu gerekçeyle birden fazla konutu olup toplamda 5.227.000 TL'nin üzerinde olan mükelleflerin de vergilendirilmesi daha yerinde olacaktır.

Değerli konut vergisine ilişkin artan oranlı binde 3, binde 6 ve binde 10 olmak üzere üç farklı dilimi olan bir tarife kanunda öngörülmüştür. Emlak vergisinin oranları ise taşınmazın mesken, arazi ve büyükşehir sınırları içerisinde yer alıp almamasına göre farklılık göstermektedir. Değerli konut vergisi artan oranlı vergi tarifesine sahip olması gerekçesiyle vergilemede adalet ilkesine daha uygundur. Emlak vergisi için de artan oranlı vergi tarifesinin belirlenmesi daha yerinde olacaktır.

Emlak Vergisi Kanunun 40. maddesinde bina ve arazilerine ilişkin zamanaşımının, bina ve arazilerin bildirim dışı bırakıldığının idare tarafından öğrenildiği tarihi takip eden yılın başından başlayacağının düzenlenmesine rağmen değerli konut vergisine ilişkin kanunda ve uygulama genel tebliğinde bu hususa ilişkin bir düzenleme bulunmamaktadır. Değerli konut vergisine ilişkin de bu hususa açıklık getirilip, zamanaşımı- 
nın başlamasının idarenin öğrendiği tarihe bağlanması daha yerinde olacaktır.

Kanunda ve uygulama genel tebliğinde yer verilmeyen bir diğer husus da değerli konut vergisine tabi olan mükelleflerin emlak vergisine tabi olup olmayacağıdır. Yasal düzenlemelerde bu hususa değinilmemesi değerli konut vergisi ödeyen mükelleflerin aynı zamanda emlak vergisine de tabi olacağ 1 anlamına gelmektedir. Vergilemede hukuki güvenlik ilkesi açısından ve mükelleflerin vergisini ödeme noktasında tereddüt etmemeleri bakımından bu hususa da kanunda açıklık getirilmesi yerinde olacaktır.

Emlak vergisi ve değerli konut vergisinin karşılaştırmalı olarak incelenmesi neticesinde benzer yönlerinden çok farklı yönleri bulunduğu sonucuna ulaşılmıştır. İki vergi arasındaki farklı yönlerin fazla olması ve mükellefleri vergi ödeme noktasında tereddüte düşürecek bazı hususlara Emlak Vergisi Kanunun değerli konut vergisini düzenleyen hükümlerinde açıklık getirilmemesi gerekçesiyle görüşümüz, değerli konut vergisinin Emlak Vergisi Kanunu içerisinde değil de ayrı bir kanun olarak ayrıntılı olarak düzenlenmesinin daha yerinde olacağı yönündedir. 


\section{EXTENDED ABSTRACT}

\section{An Examination of the Valuable House Tax by Comparıng It with Municipal Taxes and Considering Its Special Status

\author{
Bilecik Şeyh Edebali Univesity
} \\ Şebnem Ekeryılmaz- Semra Altıngöz Zarplı}

As a new tax regulation, the Valuable Housing Tax (VHT) covers residential properties with a building tax value of over TRL 5,227,000 amended amount, which applies from 1.1.2021. The study carried out a detailed examination of this new regulation.

VHT has some similarities with the real estate tax on which it is based. These issues taxation on residential properties, taxpayers, ad valorem taxation, and the termination of the obligation.

The different aspects that distinguish the VHT from the real estate tax are its scope, exemptions and derogations, the beginning of the obligation, the assessment, accrual, and collection of the tax, the payment time, rate, tariff, and the absence of the repentance and improvement provisions.

The residential real estate concept refers to both residential buildings and each independent section in buildings that consist of more than one autonomous section. The Valuable Housing Tax Application General Communique published by the Revenue Administration states that each independent section will be taxed separately.

Valuable housing tax, as the name suggests, only covers housing. Immovable properties used other than residential purposes, such as workplaces, are not covered by the VHT.

According to the Valuable Housing Tax Application General Communiqué, if the residential property's VHT value in the coming years remains below the amount specified by the law in the declaration year, in this case, there will be no need to submit a tax declaration for the relevant year, in case the taxpayer documentarily proves this situation and informs the tax office. 
Valuable Housing Tax Implementation General Communiqué states that even if valuable housing taxpayers submit their declaration and pay the first installment but sell their property before the second portion arrives, that is, before August, they will continue to be taxed for their properties. Even if the taxpayers sell their residential properties, their obligation to pay the VHT installments during the year continues. Even though the taxpayers sell his real estate between January 1 and February 20, when the liability begins, they will include this real estate in their declaration and be obliged to pay the entire tax. Even though the taxpayer has sold the immovable, the continuation of his obligation within the relevant year is stipulated in the communiqué as a security measure to prevent non-payment of tax. The liability of the person who buys the residential real estate will start from the following year if it exceeds the amount specified in the law in the following year.

This issue has been included in the Valuable Housing Tax Application General Communiqué, and there is no explicit regulation regarding this situation in the Real Estate Tax Law. Clarification of this situation in the law would be appropriate in terms of legal security and certainty principles to avoid taxpayers hesitating on the relevant issue and paying their taxes late.

The Valuable Housing Tax Application General Communiqué requires that the taxpayers who own over one residential real estate submit a notification form to the tax office within the period of filing the relevant VHT declaration in order to exempt the lowest-value residential real estate from tax.

Tax laws draw a general framework regarding the subject, taxpayers, exemptions and derogations, rates, and tariffs of taxes. Detailed information on implementing taxes is available in the general application communiqués. As an example of this situation in the VHT: Although there is no regulation in the law that the obligations of VHT taxpayers selling their immovable properties during the relevant year will continue for tax installments throughout the year, this article exists in the Valuable Housing Tax Application General Communique. Since elaborating everything on the laws will make them complex and lengthy, additional details are announced with general communiqués. However, the fundamental issues that will prevent the taxpayers from hesitating to pay taxes should 
exist in the laws. Otherwise, this situation may cause taxpayers not to pay taxes or to pay incomplete or late. This application will both delay the transfer of taxes to the treasury and lead taxpayers to face some tax penalties, albeit unintentionally. In order to prevent such adverse situations and not violate the rule of law principle in our Constitution, complying with certainty in taxation and legal security, it would be more appropriate to include such primary issues in the laws.

In the study, as a result of the comparative examination of the property tax and the VHT, it has been concluded that the two taxes have more different aspects than their similarities. For this reason, the study recommended that it would be more appropriate to legislate the VHT as a separate law to regulate the provisions in more detail.

\section{Kaynakça/References}

Adam, S. ve Browne, J. (2006). A survey of the UK tax system. The Institute For Fiscal Studies.

Arpacı, A. (2014). Müşterek (Paylı) mülkiyette pay üzerinde intifa hakkı kurulmasının diğer paydaşlara etkisi. Marmara Üniversitesi Hukuk Fakültesi Hukuk Araştırmaları Dergisi, 20(1), 981-988.

Çelikkaya, A. (2020). En son servet vergisi reformlarının analizi. Maliye Dergisi, Ocak-Haziran 2020, 178, 240-262.

Çetinkaya, Ö. Mahalli İdareler Maliyesi. Bursa: Ekin Kitabevi, s.73.

Duran, D. Ş. (2019, November). Türkiyenin yeni vergi mimarisinde yeni bir vergi: Dijital hizmetler vergisi. In International Congress Of Management Economy And Polcy 2019 Autumn Proceedings Book, s.666-682.

Karagöz, N., I, ve Metin Arslan. (2019). Bina vergisine esas rayiç bedellerin belirlenmesinde yaşanan sorunların analizi: Kayseri İli Talas İlçesi örneği. İdealkent, 10(27), 840-873.

Kılıçaslan, H. ve Yavan, S. (2017). Rant vergisi: Avusturya ve İsviçre örnekleri ve Türkiye'ye ilişkin bir değerlendirme. Journal Of Economics \& Administrative Sciences/Afyon Kocatepe Üniversitesi Iktisadi Ve Idari Bilimler Fakültesi Dergisi, 19(1), 47-60.

Kızılot Ş. ve Taş M. (2013). Vergi hukuku ve Türk vergi sistemi. Ankara: Gazi Kitabevi. 
Küpeli, İ. ve Saygın, Ö. (2019), Emlak vergisi değeri ve piyasa değeri arasındaki farka bağlı vergi kayıpları: Gebze örneği. BMIJ, 7(5), 2372-2384 Doi: Http://Dx.Doi.Org/10.15295/Bmij.V7i5.1369.

Hines, J. R. (2000). What is benefit taxation, Journal Of Public Economics, 75(3), 483-492.

Organ, İ. ve Çiftçi, T. (2015). Türkiye'de emlak vergisi uygulamasından kaynaklanan sorunlar ve çözüm önerileri. Niğde Üniversitesi İktisadi Ve İdari Bilimler Fakültesi Dergisi, 8(4), 127-147.

Ökmen, M. ve Yurtsever, H. (2010). Kentsel planlama sürecinde oluşan kamusal rantın vergilendirilmesi. Maliye Dergisi, 158(06.10), 58-74.

Ömür, Ö. M. ve Gerçek, A. (2017). Türkiye ve Avrupa Birliği Üyesi ülkelerde servet vergilerinin karşılaştırılması. Manisa Celal Bayar Üniversitesi Sosyal Bilimler Dergisi, 15(2), 197-216.

Önder, A. (2018). Yerel kamu hizmetlerinin taşınmaz vergi değerlerine etkisi. (Doktora tezi). Ankara Üniversitesi, Fen Bilimleri Enstitüsü, Gayrimenkul Geliştirme Bilim Dalı, Ankara.

Öz, E., Kutbay, H. ve Buzkıran, D. (2014). Türk servet vergisi sistemine modern bir yaklaşım. Gümrük Ve Ticaret Dergisi, 2(4), 86-99.

Özkan, A.F., Rekabet Perspektifinden Dijital Hizmet Vergisi. “Vergi Düzenlemelerinin Rekabet Süreçlerine Etkileri", Siyasal Kitabevi, Ankara, Ekim 2020, Isbn: 978-605-7877-75-8, S.121-161.

İşler, İ., ve Tümer, Ö. (2020). Vergi gelirleri perspektifinden değerli konut vergisi uygulamasının değerlendirilmesi.Vergi Raporu, 249, 265-278.

Pehlivan, O. (2014). Kamu Maliyesi, Trabzon: Celepler Matbaacılık.

Pehlivan, O. (2020). Vergi Hukuku Genel Hükümler Ve Türk Vergi Sistemi. Trabzon: Celepler Matbaacılık Yayın Ve Dağıtım.

Saraçoğlu, F., Çakar, E. P. ve Çakır, M. (2015). Rant vergisi ve ülkemizdeki tartışmalar. Gazi Üniversitesi İktisadi Ve İdari Bilimler Fakültesi Dergisi, 17(3), 83-99.

Şenyüz, D., Yüce, M. ve Gerçek, A. (2015). Türk Vergi Sistemi, 12. Baskl, Bursa: Ekin Yayinları.

Töremen E. (2020). Emlak vergisine esas arsa birim değerlerinin belirlenmesindeki sorunlar ve çözüm önerileri. Niğde Ömer Halisdemir Üniversitesi Sosyal Bilimler Enstitüsü Dergisi, 2(1), 21-42.

1319 Sayılı 29.7.1970 tarihli Emlak Vergisi Kanunu

213 Sayılı 4.1.1961 tarihli Vergi Usul Kanunu

4721 Sayılı 22.11.2001 tarihli Türk Medeni Kanunu. 
4751 Sayılı 3.4.2002 tarihli Vergi Usul Kanunu, Emlak Vergisi Kanunu ve Harçlar Kanununda Değişiklik Yapılmasına İlişkin Kanun.

31365 Sayılı Resmi Gazetede yayımlanan 15.1.2021 tarihli Gelir İdaresi Başkanlığ1 Değerli Konut Vergisi Uygulama Genel Tebliği.

31349 Sayılı Mükerrer Resmi Gazetede yayımlanan 29.12.2020 tarihli Hazine ve Maliye Bakanlığının Emlak Vergisi Kanunu Genel Tebliği.

7194 Sayılı 7.12.2019 tarihli Dijital Hizmet Vergisi ile Bazı Kanunlarda ve 375 Sayılı Kanun Hükmünde Kararnamede Değişiklik Yapılması Hakkında Kanun.

Anayasa Mahkemesinin 1.11.2017 tarihli 2016-43 Esas Sayılı 2017-146 Sayılı Kararı.

Local Government Financial Statistics (2020)https://www.gov.uk/government/statistics/local-government-financialstatistics-england-2020 Erişim Tarihi:10.04.2021

\section{Kaynakça Bilgisi/Citation Information}

Ekeryılmaz, Ş. ve Altıngöz Zarplı, S. (2021). Değerli konut vergisinin belediye vergileri ile karşılaştırmalı olarak ve özellik arz eden durumları çerçevesinde incelenmesi. OPUS- Uluslararası Toplum Araştırmaları Dergisi, $\quad$ 18(44), 8362-8388.

DOI:10.26466//opus.933217. 